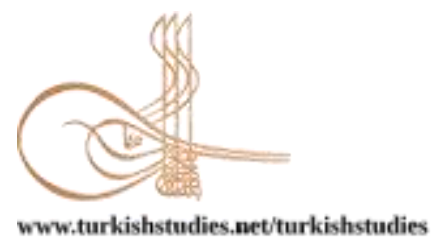

Turkish Studies

\title{
Öğretmenlerin Oyun Yaklaşımının Okul Öncesi Eğitime Etkisine Yönelik Görüşleri: Trabzon İli Örneği
}

\author{
Teachers' Views on the Effect of Game Approach on Preschool Education: The Case of Trabzon \\ Province
}

\author{
Volkan Bozlar* - Sinan Ayan**
}

\begin{abstract}
Game play for children in preschool is equal to the meaning of life. Game play is where children can be freely organized due to their creativity, and is also educationally important for both children and adults. It is also used as a powerful tool in education in terms of enabling children to learn, develop their skills, habits and gain experience. In reaching the desired goals and quality of education in pre-school education, the attitudes and opinions of the preschool teachers about the teaching of the game are important. The aim of this research was to examine the teachers' opinions on the effects of the game approach widely used in the preschool education on the abilities of learning and application and, improvement of students. The main population of the research was the preschool teachers working at the public and private schools of the Ministry of Education in Trabzon province. "Personal information form" and "The assessment scale of teachers" views the game method in the preschool education". The main ddescriptive statistics (frequency, arithmetic mean, standard deviation, minimum and maximum values) and t-test were used in the analysis of the data. Research findings revealed that teachers in public schools evaluated the impact of the game on students' development more positively than those in private schools. The teachers though that the most impact of the game approach was on the development of the students and the least effect of game method was on their skill abilities. The same subject should be actually investigated in other provinces for mapping the profile of country.
\end{abstract}

Structured Abstract: The aim of this research was to examine the teachers' opinions on the effects of the game approach, widely used in pre-school education on the abilities of learning and application and the improvement of students. The main population for the descriptive research model consists of preschool teachers working in public and private schools within the Department of Education in the province of Trabzon. A "Personal information form" and an "Assessment scale of Game Play in Preschool Education According to Teachers' Views", were used to collect the data. The main descriptive statistics (frequency, arithmetic mean, standard deviation, minimum and maximum values) and t-test were used in the analysis of the data. The results of the study revealed that; the biggest effect of game play was the development of the

\footnotetext{
* Dr. Öğrencisi, Kırıkkale Üniversitesi, Spor Bilimleri Fakültesi, Beden Eğitimi ve Spor Bölümü

PhD. Student, Kirlkkale University, Faculty of Sport Sciences, Department of Physical Education and Sport ORCID 0000-0001-8576-2984

volkanbozlar@hotmail.com

** Prof. Dr. Kırıkkale Üniversitesi, Spor Bilimleri Fakültesi, Beden Eğitimi ve Spor Bölümü

Professor, Kirlkkale University, Faculty of Sport Sciences, Department of Physical Education and Sport ORCID 0000-0001-9223-7969
}

sayan@kku.edu.tr

Cite as/ Atıf: Bozlar, V., Ayan, S. (2020). Öğretmenlerin oyun yaklaşımının okul öncesi eğitime etkisine yönelik görüşleri: Trabzon ili örneği. Turkish Studies, 15(3), 1699-1708. https://dx.doi.org/10.29228/TurkishStudies.43375

Received/Geliș: 04 May/Mayıs 2020

Accepted/Kabul: 20 June/Haziran 2020

Checked by plagiarism software

Copyright $($ C MDE, Turkey

Published/Yayın: 25 June/Haziran 2020

CC BY-NC 4.0 
child, according to the teachers who participated in this research. It has been determined that the teachers who are in the '31 years old and over' group expressed more positive opinions about the effects of game play on the application when compared to the teachers in the ' 30 and under' age group. This study has also revealed that the teachers working in public schools thought more positively, than the teachers working in private schools about the effects of game play in child development. In addition, it was concluded that the teachers with more than 'ten years experience' thought more positively, about the effects that game play had in child development, than teachers with 'ten years or less experience'.

Education with the use of game play, which is an indispensable element of basic education all over the World, is just one of the tools that teachers use to reach the goals of education, if used properly, it is perhaps the most effective (Ayan ve Dündar, 2009). In his study, Artar (1999) found that teachers absolutely believed that the game is a developer, Y1lmaz (2006) concluded that musical play activities increased children's motivation to learn, and Hanline et al. (2010) in their study; showed that preschool children with building blocks skills, stood out as having better reading skills.

On the other hand, Akınbay (2014)'s study, investigating the effects of game play on the motor performances of preschool children; stated that the games played within the experimental group positively affected the childrens' balance, bouncing, jumping, catching, running, long jumping and tennis ball throwing skills. In addition, Kacir (2015) found that the level of social emotioanl adjustment of preschool children (6072 months) had increased when educational games were played, and in a study by Carlson and white (2013), it was found that even a small animation game under 10 minutes gave children the ability to think flexibly.

Considering that game play is an essential tool in the education of children, the attitudes and opinions of preschool teachers regarding play teaching are important in achieving the desired goals and quality of education in preschool education (Kadim, 2012). The teachers within the scope of the study, stated that the biggest effect of game play was on the development and the least effect was on the practical skills of the students (Table 2). In addition, as a result of our study, in terms of age variable; it has been found that the teachers who are '31 years old and over', expressed more positive opinions about the effects of application of game play, than the teachers in the '30 and under' age group (Table 3). Unlike ours, in the study of Bozan (2014), there was no significant difference between the opinions of teachers in this dimension, while in the other two sub-dimensions ("Effects of Game Play on Learning" and "Effects of Game Play on Development"), as there was a significant difference found in favor of preschool teachers aged 41 and over when compared to the younger ones. The reason for this may be that teacher views vary due to geographical and regional differences.

Another finding in our study was that when the teachers' opinions were evaluated according to the school type variable, the average scores of the teachers working in public schools were higher only in the 'Impact of the Game Development' sub-dimension (Table 4). In his study, Bozan (2014) concluded that the opinions of preschool teachers regarding play activities are not significantly different, when evaluated according to the type of school variable (Primary and Kindergarten). The reason for this may also be a reflection of teachers having different perspectives.

When the opinions of the teachers who participated in our study about game play were evaluated in terms of work experience variable; it was found that the average scores of the participants with 11 or more years of experience were higher compared to those who served for 10 years or less in the "İmpact of Game Play on Development" sub-dimension (Table 5). In the study of Bozan (2014), unlike our study, there was no significant difference between the opinions of teachers in this dimension, however, the effect of game play on learning found that the opinions of teachers who have worked (1-5 years) and those who have worked (21 years and over) were more positive than the teachers classified between these two age groups.

Although the place and importance of playing games in childrens lives are now known to everyone, this study reflects the opinions of the teachers about the effect of the game play in practice and, the development and learning of children in preschool education; it revealed that they differ in terms of the variables discussed. Since this research is the second study using the same scale, current studies in different provinces or regions can also help to reveal a general view of teachers' opinions, if any. This additional information which includes improving the curriculum that field professionals prepare or will prepare, can contribute to the plans and policies to be carried out in terms of development and enrichment.

Keywords: Preschool education, Child, Game method, Teacher opinions, Trabzon province. 
Öz: Okul öncesi dönemdeki çocuklar için oyun, hayatın anlamıyla aynı değerdedir. Çocukların yaratılışları gereği özgürce organize olabildikleri oyun, hem çocuklar hem de yetişkinler için eğitimsel açıdan da önem taşımaktadır. Çocukların öğrenmelerini, becerilerini geliştirmelerini, deneyim kazanmalarını ve hatta alışkanlıklarını dahi düzene sokmalarını sağlaması yönüyle de, eğitimde güçlü bir araç olarak kullanılmaktadır. Okul öncesi eğitimde istenilen amaçlara ve eğitim kalitesine ulaşılmasında, okul öncesi öğretmenlerinin oyun öğretimine dair tutum ve görüşleri önem arz etmektedir. Bu araştırmanın amac1; öğretmenlerin okul öncesi eğitimde yaygın olarak kullanılan oyun yaklaşımının öğrencilerin öğrenme ve uygulama yeteneği ile gelişimine etkisine ilişkin görüşlerinin ortaya konulmasıdır. Araştırmanın çalışma grubunu, Trabzon İlinde Milli Eğitim Bakanlığı'na bağlı resmi ve özel okullarda okul öncesi sınıflarda görev yapan öğretmenler oluşturmuştur. Araştırmada veri toplama aracı olarak, 'Kişisel Bilgi Formu' ve 'Okul Öncesi Eğitimde Oyunun Öğretmen Görüşlerine Göre Değerlendirilmesi Ölçeği' kullanılmıştır. Verilerin analizinde betimleyici istatistikler (frekans, aritmetik ortalama, standart sapma, minimum ve maksimum değerler) ve t-testinden yararlanılmıştır. Araştırma bulguları, resmi okullardaki öğretmenlerin özel okullardakilere göre oyunun öğrencilerin gelişimleri üzerine olan etkisini daha pozitif değerlendirdiklerini ortaya koymaktadır. Öğretmenler, oyunun en fazla etkisinin öğrencilerin gelişimlerine, en az etkisinin ise uygulama becerilerine olduğunu düşünmektedirler. Bu konuda diğer iller ve bölgelerde yapilacak güncel çalışmalarla ülke profilinin çıkartılması yararlı olacaktır.

Anahtar Kelimeler: Okul Öncesi Eğitim, Çocuk, Oyun Yöntemi, Öğretmen Görüşleri, Trabzon Örneği.

\section{Giriş}

Akandere (2004), oyun ve oyuncak tarihinin oldukça eski olduğunu, tarihsel olarak çocukların genellikle kendi oyunlarını kendilerinin şekillendirdiğini veya kendilerinden önce var olan oyunları, üzerinde birtakım değişiklikler yaparak sürdürdüklerini, günümüzde oynanan oyunların birçoğunun geçmişte de var olduklarını, oyun vasıtası olarak ise; taş, top ve ip gibi aletlerin kullanıldığını bildirmektedir (Başal, 2007). Birçok bilim adamı, çocuğu tanımada ve tahlil etmede en iyi yolun oyun olduğunu savunmaktadırlar (Ayan ve Memiş, 2012). Güneş (2013)'e göre çocuklar, kendilerine has dünyaları içerisinde yoğun bir düş gücüne sahip olduklarından; bu düş güçleri sayesinde dünyayı kendi etraflarında döner görürler. Kendi hallerinde oyun oynarlarken, bir yastığın onlar için bir anda bir at haline geldiğini, iki basit tahta parçasının köprüye ve yola dönüştüğünü ve oyun içinde onlar için bambaşka amaçlar için kullanılmak üzere bir vasıta haline geldiği görülebilir (Bozan, 2014).

Okul öncesi dönemdeki çocuklar için oyun, hayatın anlamıyla aynı değerdedir. Çocukların yaratılışları gereği özgürce organize olabildikleri oyun, hem çocuklar hem de yetişkinler için eğitimsel açıdan da önem taşımaktadır. Çocukların öğrenmelerini, becerilerini geliştirmelerini, deneyim kazanmalarını ve hatta alışkanlıklarını dahi iyileștirmelerini sağlaması yönüyle de, eğitimde güçlü bir araç olarak kullanılmaktadır (Petrovska ve ark. 2013). Güneş (2013)'e göre oyun içinde çocuk; başkalarıyla diyalog kurar, iş birliği yapar, yardımlaşır ve karşılaştığı güçlüklerin üstesinden gelmeyi öğrenmek gibi kazanımlar elde eder. Başkalarıyla oyun oynamak için onlarla iyi geçinmesi gerektiğinin farkına varmak gibi, her zaman kendisine lazım olacak olan sosyal kuralları da yine oyunla birlikte öğrenir (Bozan, 2014). Dolayısıyla çocukların eğitimi ve kişiliklerinin gelişiminde, çocuk oyunlarının önemi büyüktür. Çocuk, oyunun doğal akışı içerisinde arzu edilen davranışları öğrenir, bilinçlenir ve kabiliyetlerini geliştirme olanağı bulur. Ayrıca oyun içinde; mücadele eder, sahip olduğu hakların, bazı kavramların ve toplumsal kuralların farkına varır. Oyunun çocuğun gelişimine; bedensel, zihinsel, sosyal ve psikolojik açıdan olumlu etkisi vardır (Ö̈zer ve ark. 2006). Hatta öyle ki; bir çocuğun fiziksel ve zihinsel yönden sağlıklı yetişmesi ve gelişmesinde beslenme ve uyku ne kadar önemliyse, oyun da o kadar önemli bir yer teşkil etmektedir (Aral, 2001). 
Thomas ve ark. (2006), oyun etiketi ile yapılan etkinlerde, okul öncesi dönem çocuklarının daha başarılı olduklarını ortaya koymuşlardır (Koçiğit ve Baydilek, 2015). Howard ve McInnes (2012) çalışmalarında; çocukların dikkatlerini toplama ve bunu devam ettirebilmelerinde, oyun gibi etkinliklerde daha fazla motive oldukları, daha çok gülümsedikleri ve çok daha başarılı olduklarını tespit etmişlerdir. Yapılan araştırmalarda, çocuğun gelişimi üzerinde okul öncesi eğitimin ve eğitim niteliğinin uzun vadeli etkileri olduğu ortaya konulmuştur. Dolayısıyla, toplum için arzu edilen özellik ve donanımlara sahip bireylerin yetişmesinde, okul öncesi dönemde alınan eğitimin önemli rolü vardır (Akyel, 2011).

Okul öncesi dönem, çocukların doğal yeteneklerini ve yaratıcılıklarını ortaya koyabilmeleri için onlara uygun fiziksel ortamın sunulduğu (Yıldır, 1991), doğuştan sahip oldukları kapasitenin optimum seviyeye çıkartılması noktasında her yönüyle hayata hazırlanıldığı (Kadim, 2012) ve hayatlarının sonraki dönemlerinin temellerinin atıldığı (Başal, 2005) bir dönem olması hasebiyle önem arz etmektedir. Okul öncesi eğitim kurumları, çocuğu toplumsal yaşama hazırlamada aileden sonra gelen destekleyici bir kurum niteliği taşımaktadır (Durualp ve Aral, 2010). Bu bağlamda okul öncesi dönemde, çocukların akran ilişkilerinin temelleri atılmakta, sosyal ilişkilere dair önemli deneyimler kazanılmakta ve beceriler elde edilmektedir (Darıca, 2004). Çocukların eğitiminde oyunun temel bir araç olduğu göz önünde bulundurulduğunda, okul öncesi eğitimde istenilen amaçlara ve eğitim kalitesine ulaşılması noktasında, okul öncesi öğretmenlerinin oyun öğretimine dair tutum ve görüşleri önem arz etmektedir (Kadim, 2012).

Literatürde okul öncesi eğitime oyun yönteminin etkisini ele alan çok sayıda yerli ve yabancı çalışmaya rastlanılmıştır. Şöyle ki; Akyel (2011) okul öncesi öğretmenlerin drama yöntemi yeterliklerini, Kadim (2012) okul öncesi öğretmenlerinin oyun öğretimine yönelik öz yeterliklerini, Artar (1999) okul öncesi öğretmenlerinin çocukların oyun hakkına ilişkin tutumlarını, Bozan (2014) ise öğretmenlerin oyunun okul öncesi eğitime etkisi konusundaki görüşlerini araştırmışlardır. Ayan ve Dündar (2009) yaratıcılığın ve oyunun okul öncesi eğitimdeki önemini, Ayan ve Memiş (2012) ise erken çocukluk döneminde oyunun etkisini incelemişlerdir. Durualp ve Aral (2010), oyun temelli eğitiminin altı yaşındaki çocukların sosyal becerilerine etkisini, Kaya ve Elgün (2015) ise eğitsel oyunlar ile desteklenmiş fen öğretiminin ilkokul öğrencilerinin akademik başarısına etkisini ele almışlardır. Hanline ve ark. (2010)'nın çalışmasında; engelli ve engelsiz çocukların okulöncesi blok oyunu ile ilköğretimdeki okuma ve matematik becerileri arasındaki ilişki ortaya konulmuştur. Koçyiğit ve Baydilek (2015) okul öncesi dönem çocuklarının oyun algılarını, Kacır (2015) ise eğitsel oyunun, okul öncesi öğrencilerin sosyal duygusal uyumlarına etkisini araştırmışlardır. Yılmaz (2006)'ın araştırmasında müzikli oyun etkinliklerinin okul öncesi öğrencilerin sayı ve işlem kavramlarını kazanımları üzerindeki etkisi incelenmiştir. Howard ve McInnes (2012) çocukların oynamaktan ziyade bir etkinliği oyun olarak algılamalarının duygusal refahları üzerindeki etkisini, Özer ve ark. (2006) oyunun çocuk gelişimine etkisini, Akınbay (2014) okul öncesi dönemde oyunun çocukların motor gelişimleri üzerine etkisini ve Kuru (2012) ise oyunun 9 yaş çocukların psikomotor gelişimlerinde etkisini araştırmışlardır.

$\mathrm{Bu}$ araştırmanın amacı; öğretmenlerin okul öncesi eğitimde oyun yaklaşımı kullanılmasının öğrencilerin öğrenme, uygulama yeteneği ile gelişimine etkisine ilişkin görüşlerinin ortaya konulmasıdır. Elde edilen araştırma bulgularının, hem konuyla ilgili yapılmış daha önceki çalışmalara katkı sağlayacağ bilgiler sunacağı, hem de yeni çalışmalara yol göstereceği düşünülmektedir.

\section{Yöntem}

\section{Araştırma Modeli}

$\mathrm{Bu}$ araştırmada, sosyal bilimlerde yaygın olarak kullanılan tarama yöntemi kullanılmıştır (Karakaya, 2012). Geçmişte ya da halen var olan durumu var olduğu şekliyle betimleme amacı taşıyan tarama yönteminde (Kuzu, 2013), araştırmaya konu olan olay, birey ya da nesnenin kendi 
koşulları içinde olduğu gibi tanımlanabilmesi ve mevcut durumun değiştirilmeye kalkmadan gözlenebilmesi önem taşımaktadır (Karasar, 2012). Araştırmanın temel verilerinin derlenmesinde ise anket tekniğinden yararlanılmıştır (Nachmias ve Nachmias, 1996).

\section{Çalışma Grubu}

Araştırmanın çalışma grubunu, 2016-2017 Eğitim-Öğretim yılında Trabzon ilindeki Milli Eğitim Bakanlığı'na bağlı resmi okullarda görev yapan 65 ve özel okullarda görev yapan 69 olmak üzere toplam 134 okul öncesi öğretmeni oluşturmuştur.

\section{Veri Toplama Araçları}

Araştırma popülasyonunu oluşturan öğretmenlerden gerekli verilerin toplanmasında araç olarak "Kişisel Bilgi Formu" ve "Okul Öncesi Eğitimde Oyunun Öğretmen Görüşlerine Göre Değerlendirilmesi Ölçeğinden” yararlanılmıştır.

\section{Kişisel Bilgi Formu}

Araştırmacı tarafından geliştirilen 'Kişisel Bilgi Formu', araştırmaya konu olan okul öncesi öğretmenleri hakkında bilgi toplamak amacıyla, araştırmada inceleme konusu olan yaş, görev yapılan okul türü, görev yılı ve kazancını yeterli bulma durumu gibi sorulardan oluşmaktadır.

\section{Ölçeği \\ Okul Öncesi Öğretmenlerinin Oyun Etkinliklerine İlişkin Görüşlerini Belirleme}

Öğretmenlerin, okul öncesi eğitimde oyuna yönelik görüşlerini belirlemede Bozan (2014) tarafından geliştirilen 'Okul Öncesi Eğitimde Oyunun Öğretmen Görüşlerine Göre Değerlendirilmesi Ölçeği’ kullanılmıştır. Ölçek, 14 maddeden oluşan 3 faktörlü bir yapıya sahiptir. Ölçek faktörleri; 'Oyunun Öğrenmeye Etkisi' (7 madde), 'Oyunun Uygulamaya Etkisi' (4 madde) ve 'Oyunun Gelişime Etkisi (3 madde) şeklindedir. Ölçek maddeleri "3'lü Likert Tipi Ölçek" formundadır. Likert seçenekleri "Katılmıyorum (1)", "Kısmen Kat1liyorum (2)" ve "Katıliyorum (3)" ş̧eklinde sıralanmış ve puanlama da buna göre yapılmıştır. Ölçekten alınabilecek en düşük puan 14 , en yüksek puan ise 42 'dir.

\section{Veri Toplanması ve Analizi}

Araştırmada kullanılan veri toplama aracı, 2016-2017 eğitim-öğretim yılında araştırmacı tarafından gerekli izinlerin alınmasından sonra çalışma grubunu oluşturan okul öncesi 145 öğretmene uygulanmıştır. Yönergede çalışma ile ilgili detaylı bilgilere yer verilmiş ve gönüllü katılım ilkesi esas alınmıştır. Daha sonra toplanan anket formları kontrol edilmiş, eksik ya da hatalı doldurulmuş olanlar çıkarılarak, geriye kalan 134 adet anketin verileri, SPSS 21 paket programına girilerek uygun istatistiklerle değerlendirilmiştir.

Araştırma kapsamında yapılan istatistiksel analizler, SPSS 21 istatistik paket programı aracılığıyla gerçekleştirilmiştir. Verilerin değerlendirilmesinde istatistiki yöntem olarak; betimsel istatistikler (frekans, aritmetik ortalama, standart sapma, minimum ve maksimum değerler) ve ttesti kullanılmıştır. Ölçeklerin güvenirliklerini belirlemek için de Cronbach Alpha iç tutarlık katsayıları hesaplanmıştır. Toplam ölçek için iç tutarlık katsayısı, 0.83 olarak bulunmuştur.

\section{Araştırma Sonuçları}

\section{Katılımcıların Demografik Özellikleri}

Araştırmaya katılan öğretmenlerin demografik özelliklerine ait tanımlayıcı istatistikler Tablo 1'de verilmiştir. Çalışma kapsamında görüşülen öğretmenlerin 59 (\%44)'unun yaş1 30 ve altında iken, $75(\% 56)$ 'i 31 ve üzeri yaştadır. Öğretmenlerin $94(\% 70,1)$ 'ünün görev süresi 10 yıl ve daha az iken, 11 yıl ve üzeri görev yapanların sayısı ise $40(\% 6)$ 'tır. Katılımcilardan $60(\% 44 ., 8)$ '1 kazancını yeterli bulduğunu, $74(\% 55,2)$ 'ü ise kazancını yeterli bulmadığını belirtmiştir. 
Tablo 1: Öğretmenlerin Demografik İstatistikleri

\begin{tabular}{llcc}
\hline Demografik Özellik & & n & Yüzde (\%) \\
\hline \multirow{2}{*}{ Yaş } & $\leq 30$ & 59 & 44.00 \\
& $\geq 31$ & 75 & 56.00 \\
\multirow{2}{*}{ Görev Yapılan Okul Türü } & Toplam & 134 & 100.00 \\
& Resmi & 65 & 48.50 \\
& Özel & 69 & 51.50 \\
Görev Y1lı & Toplam & 134 & 100.00 \\
& $\leq 10$ Yıl & 94 & 70.10 \\
& $\geq 11$ Y1l & 40 & 29.90 \\
Kazancı Yeterli Bulma Durumu & Toplam & 134 & 100.00 \\
& Evet & 60 & 44.80 \\
& Hayir & 74 & 55.20 \\
& Toplam & 134 & 100.00 \\
\hline
\end{tabular}

\section{Ölçek Puanlarının Dağılımı ve İstatistik Test Sonuçları}

Araştırmaya katılan öğretmenlerin veri toplama araçlarından aldıkları puanların dağılımı ve istatistik test sonuçlarına ilişkin bilgiler, Tablo 2-6'da verilmiştir. Çalışma kapsamındaki katılımcıların, ölçekten aldıkları toplam puanların aritmetik ortalaması 2.50 ve standart sapması 0.23 'tür. Ölçek puanları faktör bazında incelendiğinde en yüksek ortalamanın (2.92) 'Oyunun Gelişime Etkisi' alt boyutunda, en düşük ortalamanın (2.27) ise 'Oyunun Uygulamaya Etkisi' alt boyutunda olduğu görülmektedir. Öğrencilerin toplam ölçekten aldıkları en düşük puan 1.54 iken, en yüksek puan ise 2.93 'tür (Tablo 2).

Tablo 2: BEYÖ Puanlarının Dağılımı

\begin{tabular}{lcccccc}
\hline Oyunun Etkisi & $\begin{array}{c}\text { Madde } \\
\text { Sayısı }\end{array}$ & $\mathbf{n}$ & Ort. & Ss & Minimum & Maksimum \\
\hline Öğrenme & 7 & 134 & 2.45 & 0.30 & 1.43 & 3.00 \\
Uygulama & 4 & 134 & 2.27 & 0.36 & 1.38 & 3.00 \\
Gelişim & 3 & 134 & 2.92 & 0.23 & 2.00 & 3.00 \\
Toplam & 14 & 134 & 2.50 & 0.23 & 1.54 & 2.93 \\
\hline
\end{tabular}

Öğretmenlerin toplam ölçek ve alt boyutlarından aldıkları puanların yaş değişkenine göre ttesti sonuçları, Tablo 3'te sunulmuştur. Analizler, yaş değişkenine göre toplam ölçek $(p>0.05)$ ile 'Oyunun Öğrenmeye Etkisi' ( $p>0.05$ ) ve 'Oyunun Gelişime Etkisi' ( $p>0.05)$ alt boyut puanlarının anlamlı bir şekilde farklılaşmadığını, sadece 'Oyunun Uygulamaya Etkisi' $(\mathrm{p}<0.05)$ alt boyut puanlarının anlamlı bir şekilde farklılaştı̆̆ını göstermektedir. Bu bulguya göre; 31 ve üzeri yaş grubunda yer alan katılımcıların ortalama puanları (2.33), 30 ve altı' yaş grubunda yer alan katılımcıların ortalama puanlarından (2.20) daha yüksektir.

Tablo 3: Ölçek Puanlarının Yaş Değişkenine Göre T-Testi Sonuçları

\begin{tabular}{|c|c|c|c|c|c|c|c|}
\hline \multirow{2}{*}{ Oyunun Etkisi } & \multicolumn{2}{|c|}{$\begin{array}{c}30 \text { Yaş ve Altı } \\
(n=59)\end{array}$} & \multicolumn{2}{|c|}{$\begin{array}{c}31 \text { Yaş ve Üzeri } \\
(n=75)\end{array}$} & \multirow[b]{2}{*}{$\mathbf{t}$} & \multirow[b]{2}{*}{ Sd } & \multirow[b]{2}{*}{$\mathbf{p}$} \\
\hline & Ort. & Ss & Ort. & Ss & & & \\
\hline Öğrenme & 2.42 & 0.32 & 2.48 & 0.28 & 1.08 & 132 & 0.28 \\
\hline Uygulama & 2.20 & 0.34 & 2.33 & 0.37 & 2.18 & 132 & 0.03 \\
\hline Gelişim & 2.90 & 0.27 & 2.94 & 0.20 & 0.83 & 132 & 0.41 \\
\hline Toplam & 2.46 & 0.25 & 2.53 & 0.20 & 1.88 & 132 & 0.06 \\
\hline
\end{tabular}

Öğretmenlerin toplam ölçek ve alt boyutlarından aldıkları puanların görev yapılan okul türü değişkenine göre t-testi sonuçları, Tablo 4'te sunulmuştur. Analizler, görev yapılan okul türü 
değişkenine göre toplam ölçek ( $>0.05)$ ile 'Oyunun Öğrenmeye Etkisi' ( $p>0.05)$ ve 'Oyunun Uygulamaya Etkisi' ( $>0.05)$ alt boyut puanlarının anlamlı bir şekilde farklılaşmadığını, sadece 'Oyunun Gelişime Etkisi' $(\mathrm{p}<0.05)$ alt boyut puanlarının anlamlı bir şekilde farklılaştığını göstermektedir. Bu bulguya göre; resmi okullarda görev yapan katılımcıların ortalama puanları (2.98), özel okullarda görev yapan katılımcıların ortalama puanlarından (2.87) daha yüksektir. Diğer bir deyişle, resmi ve özel okullarda görev yapan katılımcıların 'Oyunun Gelişime Etkisi' alt boyutundan aldıkları ortalama puanlar arasındaki fark, istatistiksel açıdan anlamlı bulunmuştur.

Tablo 4: Ölçek Puanlarının Görev Yapılan Okul Türü Değişkenine Göre T-Testi Sonuçları

\begin{tabular}{|c|c|c|c|c|c|c|c|}
\hline \multirow[t]{2}{*}{ Oyunun Etkisi } & \multicolumn{2}{|c|}{$\begin{array}{l}\text { Resmi } \\
(\mathbf{n}=65)\end{array}$} & \multicolumn{2}{|c|}{$\begin{array}{c}\text { Özel } \\
(n=69)\end{array}$} & \multirow[b]{2}{*}{$\mathbf{t}$} & \multirow[b]{2}{*}{ Sd } & \multirow[b]{2}{*}{$\mathbf{p}$} \\
\hline & Ort. & Ss & Ort. & Ss & & & \\
\hline Öğrenme & 2.50 & 0.26 & 2.41 & 0.32 & 1.70 & 132 & 0.09 \\
\hline Uygulama & 2.24 & 0.35 & 2.30 & 0.38 & 0.85 & 132 & 0.40 \\
\hline Gelişim & 2.98 & 0.10 & 2.87 & 0.30 & 2.85 & 83.37 & 0.01 \\
\hline Toplam & 2.53 & 0.19 & 2.48 & 0.26 & 1.32 & 125.63 & 1.19 \\
\hline
\end{tabular}

Öğretmenlerin toplam ölçek ve alt boyutlarından aldıkları puanların görev yılı değişkenine göre t-testi sonuçları, Tablo 5 'te sunulmuştur. Analizler, görev yılı değişkenine göre toplam ölçek (p>0.05) ile 'Oyunun Öğrenmeye Etkisi' (p>0.05) ve 'Oyunun Uygulamaya Etkisi' (p>0.05) alt boyut puanlarının anlamlı bir şekilde farklılaşmadığını, sadece 'Oyunun Gelişime Etkisi' $(\mathrm{p}<0.05)$ alt boyut puanlarının anlamlı bir şekilde farklılaştığını göstermektedir. Bu bulguya göre; 11 ve üzerinde görev yapan katılımcıların ortalama puanları (2.98), 10 ve daha az yıl görev yapan katılımcıların ortalama puanlarından (2.90) daha yüksektir.

Tablo 5: Ölçek Puanlarının Görev Yılı Değişkenine Göre T-Testi Sonuçları

\begin{tabular}{|c|c|c|c|c|c|c|c|}
\hline \multirow[t]{2}{*}{ Oyunun Etkisi } & \multicolumn{2}{|c|}{$\begin{array}{c}10 \text { Yıl ve Altı } \\
(n=94)\end{array}$} & \multicolumn{2}{|c|}{$\begin{array}{c}11 \text { Yil ve Üzeri } \\
(n=40)\end{array}$} & \multirow[b]{2}{*}{$\mathbf{t}$} & \multirow[b]{2}{*}{ Sd } & \multirow[b]{2}{*}{$\mathbf{p}$} \\
\hline & Ort. & Ss & Ort. & Ss & & & \\
\hline Öğrenme & 2.43 & 0.31 & 2.51 & 0.25 & 1.48 & 132 & 0.14 \\
\hline Gelişim & 2.90 & 0.27 & 2.98 & 0.12 & 2.24 & 131.87 & 0.03 \\
\hline Uygulama & 2.25 & 0.37 & 2.32 & 0.33 & 0.98 & 132 & 0.33 \\
\hline Toplam & 2.48 & 0.24 & 2.56 & 0.18 & 1.79 & 132 & 0.08 \\
\hline
\end{tabular}

Öğretmenlerin toplam ölçek ve alt boyutlarından aldıkları puanların kazancını yeterli bulma durumu değişkenine göre t-testi sonuçları, Tablo 6'da sunulmuştur. Analizler, kazancı yeterli bulma durumu değişkenine göre toplam ölçek ( $\mathrm{p}>0.05)$ ile 'Oyunun Öğrenmeye Etkisi' ( $>0.05)$, 'Oyunun Gelişime Etkisi' ( $\mathrm{p}>0.05)$ ve 'Oyunun Uygulamaya Etkisi' ( $\mathrm{p}>0.05)$ alt boyut puanlarının anlamlı bir şekilde farklılaşmadığını göstermektedir. Başka bir deyişle kazancını yeterli bulan ve bulmayan katılımcıların toplam ölçek ve alt boyutlarından aldıkları ortalama puanlar arasındaki fark, istatistiksel açıdan anlamlı değildir.

Tablo 6: Ölçek Puanlarının Kazancını Yeterli Bulma Durumu Değişkenine Göre T-Testi Sonuçları

\begin{tabular}{|c|c|c|c|c|c|c|c|}
\hline \multirow[t]{2}{*}{ Oyunun Etkisi } & \multicolumn{2}{|c|}{$\begin{array}{c}\text { Evet } \\
(\mathrm{n}=60)\end{array}$} & \multicolumn{2}{|c|}{$\begin{array}{c}\text { Hayır } \\
(n=74)\end{array}$} & \multirow[b]{2}{*}{$\mathbf{t}$} & \multirow[b]{2}{*}{ Sd } & \multirow[b]{2}{*}{$\mathbf{p}$} \\
\hline & Ort. & Ss & Ort. & Ss & & & \\
\hline Öğrenme & 2.45 & 0.31 & 2.45 & 0.29 & 0.04 & 132 & 0.97 \\
\hline Uygulama & 2.29 & 0.40 & 2.26 & 0.33 & 0.40 & 112.71 & 0.69 \\
\hline Gelişim & 2.90 & 0.26 & 2.94 & 0.21 & 1.02 & 132 & 0.31 \\
\hline Toplam & 2.50 & 0.25 & 2.50 & 0.21 & 0.01 & 132 & 1.00 \\
\hline
\end{tabular}




\section{Tartışma}

$\mathrm{Bu}$ araştırmanın amacı; öğretmenlerin okul öncesi eğitimde yaygın olarak kullanılan oyun yaklaşımının öğrencilerin öğrenme ve uygulama yeteneği ile gelişimine etkisine ilişkin görüşlerinin ortaya konulmasıdır. Tüm dünyada temel eğitimin vazgeçilmez bir unsuru olan oyunla eğitim; öğretmenlerin, eğitimin hedeflerine ulaşması için kullandıkları araçlardan sadece bir tanesi, doğru kullanıldığında belki de en etkilisidir (Ayan ve Dündar, 2009). Artar (1999) yaptığı çalışmada öğretmenlerin oyunun geliştirici olduğuna kesin olarak inandıklarını tespit etmiştir. Yılmaz (2006) araştırmasında müzikli oyun etkinliklerinin, çocukların öğrenmeye ilişkin motivasyonlarını artırdığı sonucuna ulaşmıştır. Hanline ve ark. (2010)'nın yaptıkları çalışmada; blok yapımındaki maharetleriyle öne çıkan okulöncesi çocuklarının, daha iyi okuma becerisine sahip olduklarını ortaya koymuşlardır.

Akınbay (2014), oyunun okul öncesi dönemi çocuklarının motor performanslarına etkisini araştırdığı çalışmasında; deney grubuna oynatılan oyunların çocukların denge, sekme, sıçrama, yakalama, koşma, durarak uzun atlama ve tenis topu firlatma becerilerini olumlu yönde etkilediğini belirtmiştir. Yine Kuru (2012) cinsiyet ayrımı yapmaksızın çocuklara oynattığ oyunlar sonucunda çocukların durma becerisi hariç tüm alanlarda geliştiklerini tespit etmiştir.

Kaya ve Elgün (2015)'ün çalışmalarında, Fen ve Teknoloji dersini eğitsel oyun destekli olarak alan deney grubundaki öğrencilerin başarı puanlarının, derse ilişkin kılavuz kitabı takip eden kontrol grubundaki öğrencilerin başarı puanlarından anlamlı derecede yüksek olduğunu ortaya koymuşlardır. Kacır (2015), eğitsel oyun oynatılan (60-72 aylık) okul öncesi dönem çocuklarının sosyal duygusal uyum düzeylerinin yükseldiği ortaya koymuştur. Carlson ve White (2013)'ın araştırmasında, 10 dakikanın altında küçük bir canlandırma oyununun bile çocukların performanslarını artırıcı etkisinin bulunduğunu ve çocukların; davranış ve dürtülerini başarıyla kontrol edebilmeleri için, gerekli olan esnek düşünebilme yeteneğini onlara kazandırdığını tespit etmişlerdir.

Çocukların eğitiminde oyunun temel bir araç olduğu göz önünde bulundurulduğunda, okul öncesi eğitimde istenilen amaçlara ve eğitim kalitesine ulaşılmasında, okul öncesi öğretmenlerinin oyun öğretimine dair tutum ve görüşleri önem arz etmektedir (Kadim, 2012).

Çalışma kapsamındaki öğretmenler, oyunun en büyük etkisinin öğrencilerin gelişimine olduğunu, en az etkisinin ise öğrencilerin uygulama becerisine olduğunu belirtmişlerdir (Tablo 2). Ayrıca çalışmamız sonucunda, yaş değişkeni açısından bakıldığında 31 ve üzeri yaş grubunda yer alan katılımcı öğretmenlerin ortalama puanlarının, 30 ve altı yaş grubunda yer alanlara göre sadece 'Oyunun Uygulamaya Etkisi' alt boyutunda daha yüksek olduğu ortaya çıkmıştır (Tablo 3). Bozan (2014)'ın çalışmasında ise bizimkinden farklı olarak, bu boyutta öğretmenlerin görüşleri arasında anlamlı bir farklılaşma bulunamazken, diğer iki alt boyutta (“Oyunun Öğrenmeye Etkisi' Ve "Oyunun Gelişime Etkisi”) 41 yaş ve üzeri olan okul öncesi öğretmenlerinin lehine olmak üzere, kendilerinden yaşça daha genç olanlara göre anlamlı düzeyde farklılık bulunmuştur. Bunun sebebi, coğrafi ve bölgesel farklılıklar münasebetiyle öğretmen görüşlerinin değişkenlik arz etmesi olabilir.

Araştırmamızdaki diğer bir bulgu, görev yapılan okul türü değişkenine göre öğretmen görüssleri değerlendirildiğinde, resmi okullarda görev yapan öğretmenlerin ortalama puanlarının, özel okullardakilere göre yine sadece 'Oyunun Gelişime Etkisi' alt boyutunda daha yüksek olduğu görülmüştür (Tablo 4). Bozan (2014) çalışmasında okul öncesi öğretmenlerinin oyun etkinliklerine ilişkin görüşlerinin okul türü değişkenine göre (İlkokul ve Anaokulu) anlamlı düzeyde farklılaşmadığı sonucuna ulaşmıştır. Bunun sebebi yine, öğretmenlerin farklı bakış açılarına sahip olmasının bir yansıması olabilir.

Çalışmamıza katılan öğretmenlerin oyunla ilgili görüşleri görev y1lı değişkeni açısından değerlendirildiğinde ise; 11 ve daha fazla görev süresi olan katılımcıların ortalama puanlarının, 10 
ve daha az yıl görev yapanlara göre sadece 'Oyunun Gelişime Etkisi' alt boyut daha yüksek olduğu tespit edilmiştir (Tablo 5). Bozan (2014)'ın çalışmasında ise, bizim çalışmamızdan farklı olarak bu boyutta öğretmenlerin görüşleri arasında anlamlı bir farklılaşma bulunmamış, fakat görev yılı (1-5 yıl) ve (21 yıl ve üzeri) olan öğretmenlerin 'oyunun öğrenmeye etkisi' hakkındaki görüşlerinin, bu iki yaş gurubu arasında sınıflandırılan öğretmenlere göre daha pozitif olduğu bulunmuştur. Araştırmadan elde edilen diğer bir bulgu da, kazancını yeterli bulan ve bulmayan katılımcıların toplam ölçek ve alt boyutlarından aldıkları ortalama puanlar arasındaki farkın istatistiksel açıdan anlamlı olmadığı yönündedir (Tablo 6).

\section{Sonuç}

Oyunun çocukların hayatındaki yeri ve önemi artık herkesçe bilinmekle birlikte, bu çalışma okul öncesi eğitimde oyunun uygulamaya ve çocukların gelişim ve öğrenmelerine etkisine ilişkin öğretmen görüşlerinin; ele alınan değişkenler açısından farklılık gösterdiğini ortaya koymuştur. $\mathrm{Bu}$ araştırma, aynı ölçek kullanarak yapılmış ikinci çalışma olduğundan, farklı il veya bölgelerde yapılacak güncel çalışmalar öğretmen görüşlerine dair-varsa eğer-genel bir kanının ortaya çıkmasına yardımcı olabilir. Bu ilave bilgiler, alan uzmanlarının hazırladıkları ya da hazırlayacakları müfredatın iyileştirilmesi, geliştirilmesi ve zenginleştirilmesi noktasında yürütülecek plan ve politikalara katkı sağlayabilir.

\section{Kaynakça}

Akınbay, H. (2014). Okul öncesi dönemde oyunun önemi ve çocukların motor gelişimi üzerine etkileri (Tez no. 359773) [Yüksek Lisans Tezi, Selçuk Üniversitesi Sağlık Bilimleri Enstitüsü].

Akyel, Y. (2011). Okul öncesi eğitim kurumlarında görev yapan öğretmenlerin drama yöntemi yeterliklerinin değerlendirilmesi (Tez no. 286667) [Yüksek Lisans Tezi, Ahi Evran Üniversitesi Sosyal Bilimler Enstitüsü].

Aral, N. Gürsoy F. ve Köksal A. (Eds). (2001). Okul öncesi eğitiminde oyun. Ya-Pa Ofset Yayınları.

Artar, M. (1999). Okul öncesi öğretmenlerinin çocukların 'oyun hakkı' na ilişkin tutumları. In B. Onur (Ed.), Cumhuriyet ve Çocuk, 2. Ulusal Çocuk Kültürü Kongresi Bildirileri. Ankara Üniversitesi Çocuk Kültürü Araştırma ve Uygulama Merkezi Yayınları no: 2.

Ayan, S. ve Dündar, H. (2009). Eğitimde okul öncesi yaratıc1lı̆̆ın ve oyunun önemi. Selçuk Üniversitesi Ahmet Keleşoğlu Eğitim Fakültesi Dergisi, 28, 63-74.

Ayan, S. ve Memiş, U. A. (2012). Erken çocukluk döneminde oyun. Selçuk Üniversitesi Beden Eğitimi ve Spor Bilim Dergisi, 14(2), 143-149.

Başal, H. A. (Ed.). (2005). Okul öncesi eğitiminin ilke ve yöntemleri (2. Baskı). Morpa Kültür Yayınları.

Başal, H.A. (2007). Geçmiş yıllarda Türkiye'de çocuklar tarafindan oynanan çocuk oyunları. Uludă̆ Üniversitesi Ĕ̈itim Fakültesi Dergisi, 20(2), 243-266.

Bozan, N. (2014). Okul öncesi eğitimde oyunun öğretmen görüşlerine göre değerlendirilmesi (Tez no. 381625) [Yüksek Lisans Tezi, Atatürk Üniversitesi Eğitim Bilimleri Enstitüsü].

Carlson, S. M., \& White, R. E. (2013). Executive function, pretend play, and imagination. In M. Taylor (Ed.), Oxford library of psychology. The Oxford handbook of the development of imagination (p. 161-174). Oxford University Press. 
Darıca, N. (Ed.). (2004). Okul öncesi eğitimcileri için etkinlik dünyası uygulama kitabı. Morpa Kültür Yayınları.

Durualp, E. ve Aral, N. (2010). Altı yaşındaki çocukların sosyal becerilerine oyun temelli sosyal beceri eğitiminin etkisinin incelenmesi. Hacettepe Üniversitesi Eğitim Fakültesi Dergisi, 39(39), 160-172.

Hanline, M. F., Milton, S. ve Phelps, P. C. (2010). The relationship between preschool block play and reading and maths abilities in early elementary school: A longitudinal study of children with and without disabilities. Early Child Development and Care, 180(8), 1005-1017, https://doi.org/10.1080/03004430802671171

Howard, J., ve McInnes, K. (2012). The impact of children's perception of an activity as play rather than not play on emotional wellbeing. Child, 38(1), 1-6, https://doi.org/10.1111/j.13652214.2012.01405.x

Kacır, O. (2015). Okul öncesi 60-72 aylık dönem çocuğunun sosyal duygusal uyumda eğitsel oyunun etkisi (Tez no. 422897) [Yüksek Lisans Tezi, Çanakkale Onsekiz Mart Üniversitesi Sağlık Bilimleri Enstitüsü].

Kadim, M. (2012). Okul öncesi ögretmenlerinin oyun öğretimine yönelik özeterliklerinin incelenmesi (Tez no. 304280) [Yüksek Lisans Tezi, Abant İzzet Baysal Üniversitesi Eğitim Bilimleri Enstitüsü].

Karakaya İ. (2011). Bilimsel araştırma yöntemleri. In A. Tanrıöğen (Ed.), Bilimsel araştırma yöntemleri (2.Bask1, ss:57-87). An1 Yayınc1l1k.

Karasar, N. (Ed.). (2012). Bilimsel araştırma yöntemi. Nobel Akademik Yayıncılık.

Kaya, S. ve Elgün, A. (2015). Eğitsel oyunlar ile desteklenmiş fen öğretiminin ilkokul öğrencilerinin akademik başarısına etkisi. Kastamonu Ĕ̆itim Dergisi, 23(1), 329-342.

Koçyiğit, S. ve Baydilek, N. B. (2015). Okul öncesi dönem çocuklarının oyun algılarının incelenmesi. Yüzüncü Yll Üniversitesi Eğitim Fakültesi Dergisi, 12(1), 1-26.

Kuru, O. ve Köksalan B. (2012). 9 yaş çocuklarının psiko-motor gelişimlerinde oyunun etkisi. Cumhuriyet International Journal of Education, 1(2), 37-51.

Kuzu, A. (Ed). (2013). Bilimsel araştırma yöntemleri. Anadolu Üniversitesi Yayını.

Nachmias C. F. ve Nachmias D. (Eds). (1996). Research methods in the social sciences. 5th Edition, St. Martin's Press.

Özer, A., Gürkan, A. C. ve Ramazanoğlu, M. O. (2006). Oyunun çocuk gelişimi üzerine etkileri. Doğu Anadolu Bölgesi Araştırmaları, 5(6) 67-79.

Petrovska, S., Sivevska, D., \& Cackov, O. (2013). Role of the Game in the Development of Preschool Child. Procedia-Social and Behavioral Sciences, 92, 880-884. https://doi.org/10.1016/j.sbspro.2013.08.770

Yıldır, N. (1991). Okul öncesi eğitimin önemi ve amacı. Okul öncesi Eğitimi ve Yaygınlaştırılması Semineri, Ya-Pa Yayınları.

Yılmaz, E. (2006). Okul öncesi eğitim kurumlarına devam eden 6 yaş çocuklarının sayı ve işlem kavramlarını kazanmalarında müzikli oyun etkinliklerinin kullanılmasının etkisi (Tez no. 480102) [Yüksek Lisans Tezi, Çukurova Üniversitesi Sosyal Bilimler Enstitüsü]. 